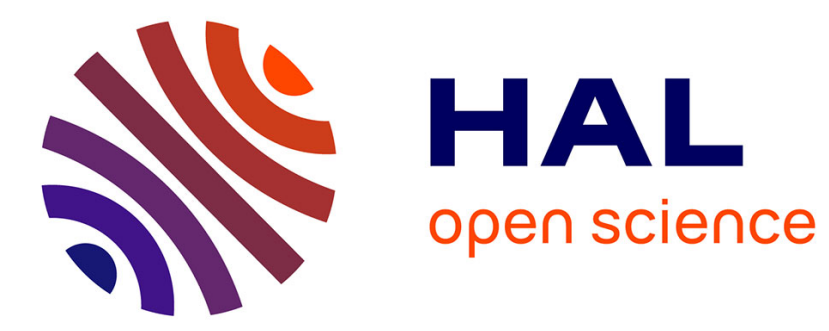

\title{
Comparison of the hygric behaviour of three hemp concretes
}

\author{
Florence Collet, Julien Chamoin, Sylvie Prétot, Christophe Lanos
}

\section{To cite this version:}

Florence Collet, Julien Chamoin, Sylvie Prétot, Christophe Lanos. Comparison of the hygric behaviour of three hemp concretes. Energy and Buildings, 2013, 62, pp.294-303. 10.1016/j.enbuild.2013.03.010 . hal-00810372

\section{HAL Id: hal-00810372 \\ https://hal.science/hal-00810372}

Submitted on 17 Aug 2020

HAL is a multi-disciplinary open access archive for the deposit and dissemination of scientific research documents, whether they are published or not. The documents may come from teaching and research institutions in France or abroad, or from public or private research centers.
L'archive ouverte pluridisciplinaire HAL, est destinée au dépôt et à la diffusion de documents scientifiques de niveau recherche, publiés ou non, émanant des établissements d'enseignement et de recherche français ou étrangers, des laboratoires publics ou privés. 


\title{
Comparison of the hygric behaviour of three hemp concretes
}

\author{
Florence Collet*, Julien Chamoin, Sylvie Pretot, Christophe Lanos \\ Université Européenne de Bretagne, Laboratoire de Génie Civil et Génie Mécanique, Equipe Matériaux Thermo Rhéologie, France
}

Hemp concrete is a bio-based building material the main qualities of which are its low environmental impact and its hygrothermal behaviour. Even for one kind of application (for example: wall), several compositions and manufacturing methods are encountered in the market. This study compares the hygroscopic behaviour of three hemp concretes used for building walls to identify whether composition and manufacturing have an impact on hygric properties. The investigations are based on the measurement of the sorption curve, of the water vapour permeability versus humidity and of the moisture buffer value. Moisture diffusivity is calculated from the sorption curve and from the water vapour permeability. The results underline the high transfer and storage capacities of these materials; they are classified as excellent (or nearly excellent) hygric regulators. A slight effect of porosity, connected with composition and manufacturing method, is observed.

\section{Introduction}

The hygrothermal behaviour of building envelopes impacts on energy needs, indoor comfort and indoor air quality. This behaviour depends on thermal and hygric properties of building materials like thermal conductivity, heat capacity, sorption curve and water vapour permeability. The use of hygroscopic materials appears as a good solution to reduce energy needs while maintaining high indoor comfort [1-4]. In order to understand and predict the hygrothermal behaviour of a building envelope implemented with such materials, numerical studies can be made. These studies are generally based on experimental data of sorption curve and water vapour permeability; and it was shown that, for hygroscopic materials, the uncertainty on this kind of data hampers reliable simulation of hygroscopic buffering [5]. In order to characterise the moisture buffering capacity of hygroscopic materials, dynamic experimental methods have thus been developed during the last 10 years [6-9]. In this study, we focus on the case of hemp concrete and we use several experimental methods to identify its hygrothermal behaviour.

Hemp concrete is a bio-based building material that was rediscovered at the end of the 20th century and has been improved over the last 20 years. Its main qualities are its low environmental impact due to bio-sourced components [10,11] and its

\footnotetext{
* Corresponding author at: IUT Génie Civil, 3, rue du Clos Cour, BP 90422, 35704 Rennes, France. Tel.: +332232340 56; fax: +33223234051.

E-mail addresses: florence.collet@univ-rennes1.fr (F. Collet), julien.chamoin@univ-rennes1.fr (J. Chamoin), sylvie.pretot@univ-rennes1.fr (S. Pretot), christophe.lanos@univ-rennes1.fr (C. Lanos).
}

hygrothermal behaviour. This material is made of hemp shiv mixed with a mineral binder. According to its composition, it can be used for several applications: wall, floor and roof. Moreover, even for one kind of application, several compositions and manufacturing methods are encountered on the market. Hemp concrete shows low compressive strength [12-14] so, it is used as filling material associated with a wooden frame. From a thermal point of view, hemp concrete shows a low thermal conductivity (about $0.1 \mathrm{~W} / \mathrm{m} / \mathrm{K}$ $[15,16])$, so it is a good insulator that can be used without an added insulation layer. From a hygric point of view, hemp concrete was characterised with steady-state methods (sorption curve, water vapour permeability). It was shown that hemp concrete has high moisture transfer and storage capacities [17,18]. Recently, hemp concrete was also characterised with a dynamic method; it was emphasised that this material is an excellent hygric regulator [19]. Finally, the hygrothermal behaviour of hemp concrete was studied at full-scale. Pretot and Collet [20] have shown that simultaneous heat and moisture flows can lead to huge vapour pressure variations in the wall linked with sorption phenomena. Shea et al. [21] have shown that the energy performance of an experimental hemp-lime building was higher than predicted from SAP rating and $U$-value calculations. It was emphasised that relative humidity influences the dynamic behaviour of hemp concrete. Numerical studies have shown that the transient hygrothermal behaviour of hemp concrete can reduce the energy demand of a building while maintaining indoor relative humidity $[22,23]$.

This study deals with three hemp concretes used for building walls. These materials differ in their composition and manufacturing methods: one of them is precast, the second one is sprayed and the last one is moulded. The aim of this study is to compare and analyse the hygroscopic behaviour of the three materials and to 
identify whether composition and manufacturing have an impact on hygric properties. The investigations are based on the measurement of the sorption curve, the water vapour permeability and the moisture buffer value. Moisture diffusivity is then calculated versus water content from the sorption curve and the water vapour permeability.

\section{Methods}

\subsection{Sorption isotherm}

The sorption isotherm relates the amount of equilibrium moisture content to the ambient relative humidity for a given temperature.

Sorption isotherms can be measured according to continuous or discontinuous methods [24]. The continuous method consists of measuring the sorption curve under quasi-equilibrium conditions. The adsorptive is admitted (or removed) at a slow and constant rate. The variation of the amount adsorbed by the specimen, with increase (or decrease) in pressure is measured by the volumetric or gravimetric method. The discontinuous method consists of measuring the amount adsorbed by the specimen at successive stages of increasing (and then decreasing) pressure. It can be performed with desiccators and saturated salt-solutions, with climatic chambers or with DVS (dynamic vapour sorption) that has been developed to reduce the running time of measurement but can be used with small specimens only [25].

In this study, the sorption isotherms are measured according to the discontinuous method: the moisture content is determined at successive stages of increasing (and then decreasing) relative humidity. The specimens are placed in a climatic chamber (Vötsch VC4060) which regulates temperature and relative humidity. They are weighed two to three times a week. The sorption isotherm is measured at $23 \pm 0.1^{\circ} \mathrm{C}$. Relative humidities used for this study are $11,23,33,43,58,81,90,95$ and $97 \% \mathrm{RH}$. The water content $w$ is calculated from the mass of the specimen (1). In order to reduce the time of exposure (to avoid moulds growing), the kinetic of water content is modelled according to (2). The test runs until the rate between the experimental variation and the variation when steadystate is reached $\tau$, defined in Eq. (3), is higher than $2 / 3$. Moreover, the calculated water content at equilibrium should also show a discrepancy lower than $0.1 \%$ between the last three fits with the kinetic model.

$w=\frac{m-m_{0}}{m_{0}}=\frac{m_{w}}{m_{0}}$

$w$ : water content (\%), $m$ : mass of wet specimen $(\mathrm{g}), m_{0}$ : mass of dry specimen $(\mathrm{g}), m_{w}$ : mass of water $(\mathrm{g})$.

$w(t)=w_{i}+\Delta w(t) ;$ with $\Delta w(t)=a[1-b \exp (-c t)]$

$w(t)$ : water content at time $t(\%), w_{i}$ : initial water content of the stage (\%), $\Delta w(t)$ : variation of water content within initial time and time $t$ of the stage (\%), $a, b$ and $c$ : fitting parameters (-).

$\tau=\frac{w_{\exp , t}-w_{i}}{w_{\infty, t}-w_{i}}$

$w_{\text {exp }, t}$ : experimental water content at time $t(\%), w_{i}$ : initial water content of the stage (\%), $w_{\infty, t}$ : water content at equilibrium, calculated with experimental values at time $t(\%)$.

Several models have been developed to describe the sorption curve [26,27]. Guggenheim [28], Anderson [29,30] and De Boer [31] have developed the GAB model (4). This model relates the water content to the specific surface area of the material for multilayer sorption. Despite it being physically valid when there is no capillary condensation; the GAB model covers a wide range of relative
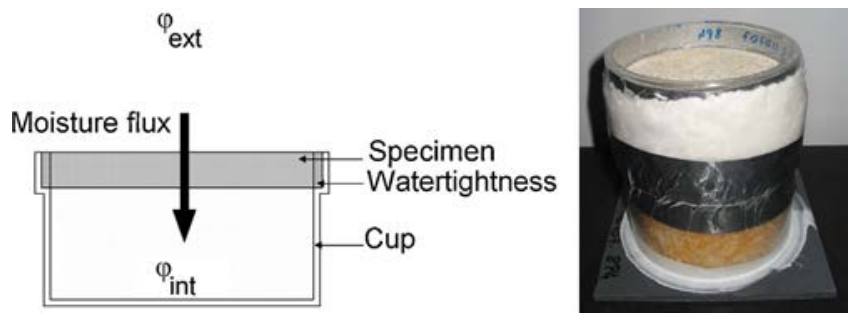

Fig. 1. Test cup.

humidity (0.05 to $0.8-0.9)$ and is convenient to fit experimental adsorption data all over the $\mathrm{RH}$ range.

$\frac{w}{w_{m}}=\frac{C_{G} \cdot k \cdot \varphi}{(1-k \cdot \varphi)\left(1-k \cdot \varphi+C_{G} \cdot k \cdot \varphi\right)}$

with $w_{m}$ : the monomolecular water content $(\mathrm{kg} / \mathrm{kg}), C_{G}, k$ : fitting parameters of the GAB model, $\varphi$ : relative humidity (-).

\subsection{Water vapour permeability}

The water vapour permeability characterises the ability of a material to transfer moisture under a vapour pressure gradient once the steady state is reached. The commonly called "vapour permeability" includes (i) vapour transfer by diffusion (transport by collision of water molecules with each other), (ii) vapour transfer by effusion (transport by collision of water molecules with walls of pores) and (iii) liquid transfer (connected with capillary condensation).

Water vapour permeability is measured according to the cup method (EN 12572, 2001) under isothermal conditions $\left(23^{\circ} \mathrm{C}\right)$ for several sets of relative humidity: (0/50), (0/23), (43/58) and (58/81). These measurements were taken in adsorption. Firstly, the specimens were dried and tests were carried out from lowest RH to highest $\mathrm{RH}$. Prior to each test, the specimens were stabilised to the lowest $\mathrm{RH}$ of the test.

The specimen is embedded at the top of the cup (Fig. 1). The relative humidity in the cup, $\varphi_{\text {int }}$, is controlled by saturated salt solutions or silica gel while the relative humidity around the cup, $\varphi_{\text {ext }}$, is controlled by air conditioning. The difference of water vapour pressures leads to a flux. The device is weighed periodically and when the gain in mass is constant, the mass rate $G$ is calculated by linear regression of the kinetic of mass and the water vapour permeability $\pi$ is then deduced:

$G=\frac{\Delta m}{\Delta t}$

$\pi=\frac{G \cdot e}{A \cdot\left(\Delta p_{v}\right)}$

where $G$ : mass rate $(\mathrm{kg} / \mathrm{s}), \Delta m$ : mass variation $(\mathrm{kg}), \Delta t$ : time (s), $\pi$ : water vapour permeability $(\mathrm{kg} /(\mathrm{ms} \mathrm{Pa})), e$ : thickness of the specimen $(\mathrm{m}), A$ : exposed surface area $\left(\mathrm{m}^{2}\right), \Delta p_{v}$ : vapour pressure difference $(\mathrm{Pa})$.

The vapour pressure is calculated from temperature and relative humidity measured during test period with the usual relationship:

$p_{v}=\varphi \cdot 100 \exp \left(18.986-\frac{4052}{235.89+T}\right)$

where $T$ : temperature $(\mathrm{K})$.

The experimental data on water vapour permeability versus relative humidity are fitted with a power law relationship according to [32]:

$\pi=A+B \cdot \varphi^{C}$ 


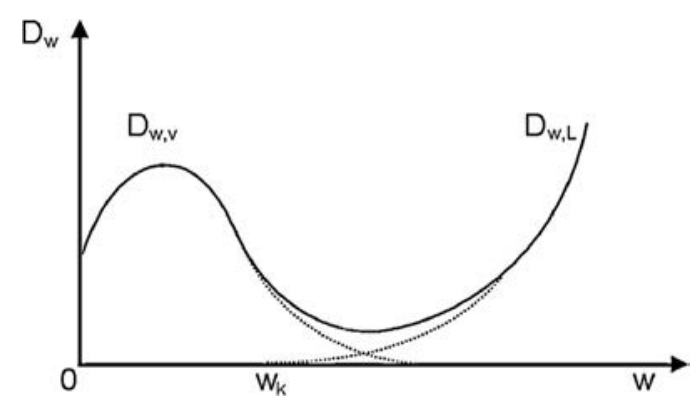

Fig. 2. Variation of hydric diffusivity versus water content according to De Vries theory [13].

\subsection{Moisture diffusivity}

Under the vapour pressure gradient, moisture transfer occurs through interconnected pores.

In an isothermal case, Fick's law states the relationship between the water vapour diffusion rate in air and the gradient of water vapour pressure:

$g_{v}=-\delta \cdot \nabla p_{v}$

where $\delta$ is water vapour diffusion permeability in air and $p_{v}(\mathrm{~Pa})$ is the water vapour partial pressure.

For building porous material, in large pores, vapour diffusion can be compared with the diffusion of water vapour in air. In small pores, the collision between molecules and pore walls are more numerous than collision between molecules: this mechanism is called effusion or Knudsen transport. Nevertheless, the effects of the porous structure can be described by water vapour diffusion resistance factor $\mu$. At a macroscopic scale, moisture transfer under a vapour pressure gradient can be expressed as

$g_{h}=-\pi \cdot \nabla p_{v}$

where $\pi=\delta / \mu$ is commonly called "the vapour permeability". It was argued that $\pi$ may be considered independent of temperature $[33,34]$.

Besides, under isothermal conditions and for one-dimensional transfer, the flux of moisture can also be calculated with:

$g_{v}=-\rho_{0} \cdot D_{u} \cdot \frac{\partial w}{\partial x}$

where $D_{u}$ is the moisture diffusivity. Thus, the moisture diffusivity $D_{w}$ of a material characterises the rate of change of its moisture content under transient moisture evolutions.

Taking the sorption isotherm into account, this equation can be rewritten as:

$g_{v}=-\rho_{0} \cdot D_{u} \cdot \frac{\partial w}{\partial \varphi} \cdot \frac{\partial \varphi}{\partial x}$

Considering that the vapour pressure gradient is linear in the specimen, the relative humidity gradient is linear too and so:

$g_{v}=-\rho_{0} \cdot D_{u} \cdot \frac{\partial w}{\partial \varphi} \cdot \frac{\varphi_{2}-\varphi_{1}}{e}=\rho_{0} \cdot D_{u} \cdot \frac{\partial w}{\partial \varphi} \cdot \frac{1}{p_{v s}} \cdot \frac{p_{v 2}-p_{v 1}}{e}$

So, moisture diffusivity is calculated from sorption and water vapour permeability versus ambient relative humidity with:

$D_{u}=\frac{\pi \cdot P_{v s}}{\rho_{0}} \cdot \frac{1}{\partial w / \partial \varphi}$

De Vries has shown that the variation of moisture diffusivity $D_{u}$ versus water content $w$ evolves according to three phenomena [35] (Fig. 2):

\section{$\operatorname{MBV}\left[g /\left(m^{2} \cdot R H\right)\right]$}

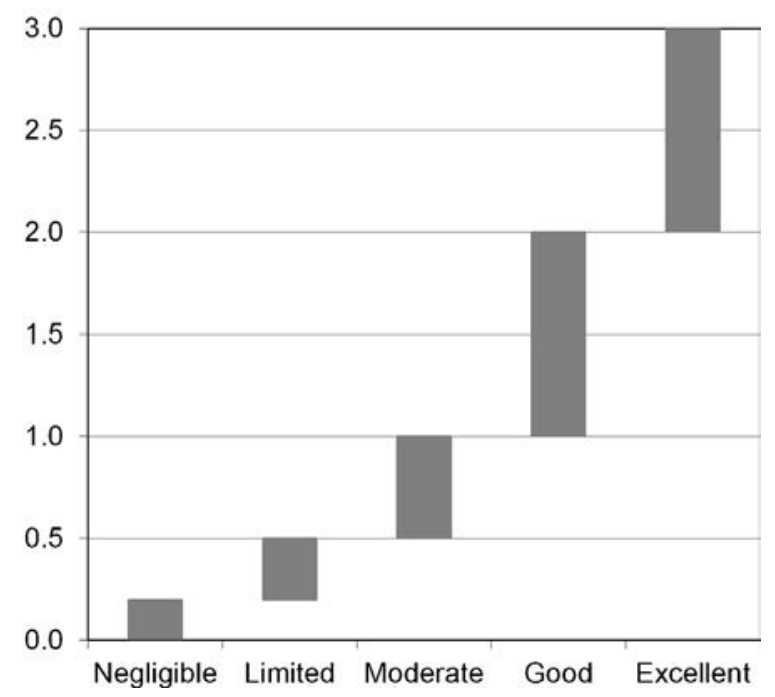

Fig. 3. Ranges for practical moisture buffer value classes [10].

- for low water content, moisture transfer is essentially due to vapour transport (diffusion and effusion). The condensed phase exists in the form of an adsorbed film or in small islands of water.

- when water content increases, small islands of water increase in number and in size, the area for vapour flux decreases and moisture transfer occurs by mechanisms of condensation and evaporation at vapour-liquid interfaces.

- then, for high water content, liquid transfer is predominant.

\subsection{Moisture buffer value}

The moisture buffer value MBV quantifies the moisture buffering ability of a material.

It is measured according to the method defined in the NORDTEST project. This project defines the practical moisture buffer value of materials, measured under dynamic conditions [36,6,37]. This value relates the amount of moisture uptake (and release), per open surface area, under daily cyclic variation of relative humidity according to Eq. (15). This value is mainly but not only a property of the material as the mass transfer coefficient at the boundary plays a role. Though, for many materials, the internal resistance to moisture transport is significantly larger than the convective surface resistance.

$\mathrm{MBV}=\frac{\Delta m}{A \cdot\left(\mathrm{RH}_{\text {high }}-\mathrm{RH}_{\text {low }}\right)}$

with MBV: moisture buffer value $\left(\mathrm{kg} /\left(\mathrm{m}^{2} \% \mathrm{RH}\right)\right), \Delta m$ : moisture uptake/release during the period $(\mathrm{kg}), A$ : open surface area $\left(\mathrm{m}^{2}\right)$, $\mathrm{RH}_{\text {high/low }}$ : high/low relative humidity level (\%).

The test method requires prismatic specimens to be sealed on five out of six sides. After stabilisation at $\left(23^{\circ} \mathrm{C} ; 50 \% \mathrm{RH}\right)$, specimens are exposed to daily cyclic variations: $8 \mathrm{~h}$ at high relative humidity (75\%) followed by $16 \mathrm{~h}$ at low relative humidity (33\%).

Within the NORDTEST project, a round robin test was held on nine representative building materials. It gave initial results and leads to a classification of moisture buffer values (Fig. 3).

The device used for MBV test consists of a climatic chamber (Vötsch VC4060) that can be controlled in the range +10 to $+95^{\circ} \mathrm{C}$ and 10 to $98 \% \mathrm{RH}$. The study is held at $23^{\circ} \mathrm{C}$. The relative humidity in the chamber is switched manually (75\%RH; 33\%RH). Temperature and relative humidity are measured continuously with Sensirion SHT75 sensors and with the sensor of the climatic chamber. The air velocity is measured in the surroundings of the specimens: the 
Table 1

Mixes proportioning and manufacturing method of studied hemp concretes.

\begin{tabular}{|c|c|c|c|}
\hline Material & $\begin{array}{l}\text { PHC: precast hemp } \\
\text { concrete }\end{array}$ & SHC: sprayed hemp concrete & MHC: moulded hemp concrete \\
\hline Manufacturing & Precasting & Spraying & Moulding \\
\hline Binder & $\begin{array}{l}\mathrm{CaO}: 72 \% \\
\text { hydraulic lime: } 28 \%\end{array}$ & Lime based binder (Tradical 70) & Lime based binder (Tradical 70) \\
\hline Hemp shiv & Usual Hemp shiv & Usual Hemp shiv & Fibered hemp shiv \\
\hline Hemp/binder mass ratio & 0.65 & 0.5 & 0.5 \\
\hline Water/binder mass ratio & 1.2 & 0.8 & 1.6 \\
\hline
\end{tabular}
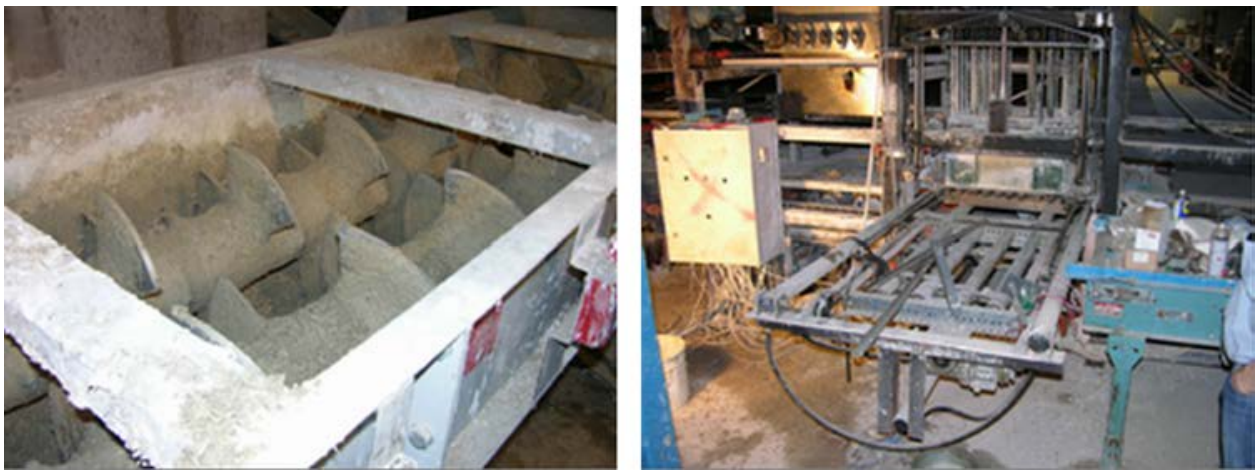

Fig. 4. Device for precasting hemp concrete (PHC) - mixer; forming process.

vertical velocity is in the range $0.07-0.14 \mathrm{~m} / \mathrm{s}$ and the horizontal one is $0.1-0.4 \mathrm{~m} / \mathrm{s}$. The specimens are weighed out of the climatic chamber five times during the absorption period and eight times during the desorption period. The weighing instrument reading is $0.01 \mathrm{~g}$, and its linearity is $0.01 \mathrm{~g}$. The accuracy of the moisture buffer value is thus about $5 \%$. According to the NORDTEST project, stability is reached when the change in mass is the same between the last three cycles with a discrepancy of less than $5 \%$.

\section{Materials}

\subsection{Composition and manufacturing}

This study deals with three kinds of hemp concrete used for building walls: a precast compacted hemp concrete, a sprayed hemp concrete and a moulded hemp concrete with fibred hemp shiv. Hemp concrete proportioning is the same as usually used by our industrial partners. For this project, hemp concrete is manufactured in moulds of $30 \mathrm{~cm} \times 30 \mathrm{~cm} \times 16 \mathrm{~cm}$. This size is representative of a wall thickness or of industrial precast blocks.
Table 1 gives the proportion of the mix and the manufacturing method of the three kinds of hemp concrete.

The precast hemp concrete (PHC) is manufactured by our industrial partner, the SME EASY Chanvre. The composition of the hemp concrete results from the optimisation of the manufacturing process used by the industrial partner. Firstly, $\mathrm{CaO}$ is mixed with water to obtain slaked lime. Then hydraulic lime and hemp shiv are added. The mixture is then poured in moulds and blocks are formed by compaction in the moulds under vibrations (Fig. 4).

The sprayed hemp concrete (SHC) is manufactured by our industrial partner SI2C. This SME applies hemp concrete by spraying in a vertical formwork. Hemp shiv and lime based binder (Tradical 70 - $\mathrm{BCB}$ ) are mixed together and constitute a dry mix that is blown along a pipe by a flow of compressed air. Water is added to the mix at the end of the pipe, the quantity of which may be controlled by the operator via one valve (Fig. 5). The commercial binder is chosen according to the setting time and hardening properties of hemp concrete. For this study, hemp concrete is sprayed in stacked moulds.
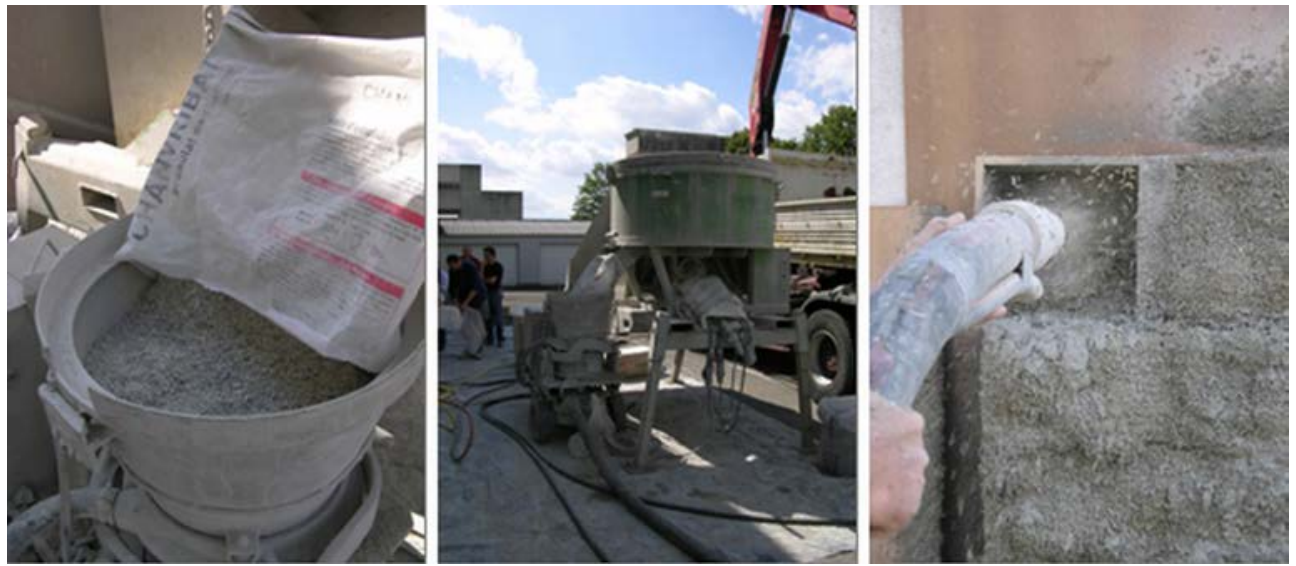

Fig. 5. Device for spraying hemp concrete (SHC) - dry mixer, shutter. 

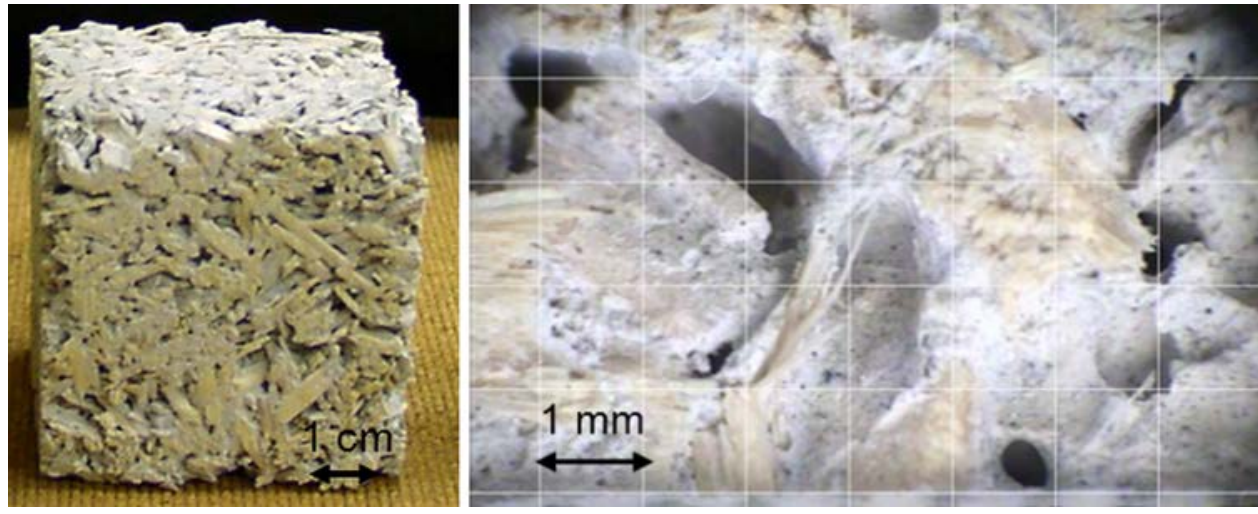

Fig. 6. Porosity of hemp concrete at macroscale.

For moulded hemp concrete (MHC), fibred hemp shiv is mixed with commercial lime-based binder (Tradical $70-\mathrm{BCB}$ ) in a mixer. Water content is adjusted to obtain fresh hemp concrete with a satisfactory rheology. Moulds are filled with the mixture and the hemp concrete is slightly compacted.

Once manufactured, blocks are stabilised at $23^{\circ} \mathrm{C}, 50 \% \mathrm{RH}$.

\subsection{Density and porosity}

Table 2 gives the apparent density at $\left(23^{\circ} \mathrm{C}, 50 \% \mathrm{RH}\right)$, the total porosity and the open porosity of studied materials.

The apparent density of the three hemp concretes ranges between 430 and $460 \mathrm{~kg} \mathrm{~m}^{-3}$. It is in the range of values commonly used for walls in France [38,39], while lower values can be met elsewhere [21]. Sprayed hemp concrete and moulded hemp concrete show similar matrix density due to the fact that these mixtures are made with the same binder and with the same binder/hemp mass ratio. Their total porosity is about $79 \%$ while the total porosity of precast hemp concrete is slightly lower: $72 \%$. Lastly, the open porosity of precast and of sprayed hemp concretes is slightly lower than $70 \%$ while it is $77 \%$ for moulded hemp concrete.

This open porosity includes a wide range of pores that are interconnected:

- at a macro scale, the porosity due to the arrangement between the hemp shiv and the hemp-binder adhesion can reach a millimetric width (Fig. 6),

- in the binder matrix, the porosity due to trapped air shows a width up to $50 \mu \mathrm{m}$ and the porosity due to hydrates arrangement is lower than $0.01 \mu \mathrm{m}$ (Fig. 7),

- in hemp shiv, the width of the porosity goes from 5 to $50 \mu \mathrm{m}$ (Fig. 8).

\subsection{Specimens}

The representative volume of hemp concrete was studied from the variation of apparent density against volume [17]. It was shown that cubic specimens with edges of $5 \mathrm{~cm}$ are representative of the material. Evrard [40] also studied the representative volume element from visual analysis. He showed that specimens larger than

\section{Table 2}

Density and porosity of studied hemp concretes.

\begin{tabular}{lrrr}
\hline Material & PHC & SHC & MHC \\
\hline Apparent density at $\left(23^{\circ} \mathrm{C} ; 50 \% \mathrm{RH}\right)\left[\mathrm{kg} \mathrm{m}^{-3}\right]$ & 460 & 430 & 430 \\
Matrix density [ $\mathrm{kg} \mathrm{m}^{-3}$ ] & 1655 & 1997 & 2002 \\
Total porosity [\%] & 72 & 78 & 79 \\
Open porosity [\%] & 68 & 66 & 77
\end{tabular}

$100 \mathrm{~cm}^{3}$ (side $>4.7 \mathrm{~cm}$ ) can take into account the specific pore and particle distribution of the material.

Specimens are cut from the blocks. Their sizes are chosen to embed the representative volume of the material. So, the specimens used for sorption curves are cylinders $5 \mathrm{~cm}$ in diameter and $7 \mathrm{~cm}$ high for sprayed and moulded hemp concrete and are cubes with edges of $5 \mathrm{~cm}$ for precast hemp concrete. The specimens used for water vapour permeability are cylinders $5 \mathrm{~cm}$ thick with an exchange surface area of $10 \mathrm{~cm}$ in diameter. Lastly, the specimens used for the moisture buffer value are a right square prism 7 to $8 \mathrm{~cm}$ thick (higher than the penetration depth) and with $15 \mathrm{~cm}$ sides. The exposed surfaces correspond to external surfaces of blocks for the MBV test and permeability test.

For each material, the numbers of specimens used are: (i) six for the sorption curve, (ii) three for the $(0 / 50 \% \mathrm{RH})$ point and one for the other points of the water vapour permeability, and (iii) six for the moisture buffer value.

\section{Results and discussion}

\subsection{Sorption isotherms}

Fig. 9 gives an example of the adsorption kinetics obtained for one specimen of sprayed hemp concrete. It is representative of the results obtained for all specimens. This figure shows the high degree of correspondence between the experimental data and the fit with the kinetic model. Thanks to this model, the time of the experiment

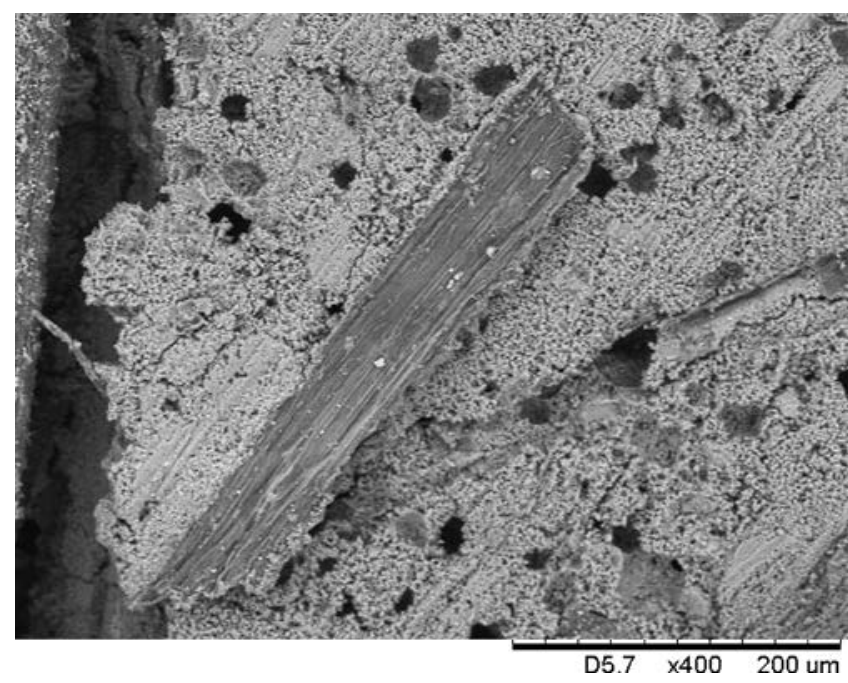

Fig. 7. MEB view of hemp concrete SHC. 

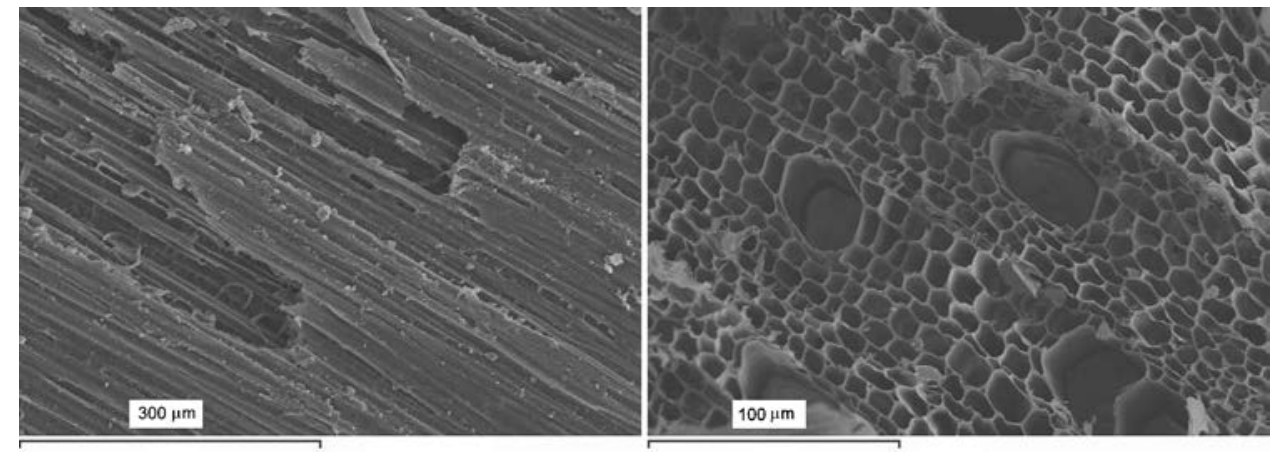

Fig. 8. MEB view of hemp shiv (left: length view, right: cross section).

is reduced to 20-40 days for each stage. The total time to measure the whole adsorption-desorption curve is about one year and nine months.

Hemp concretes are highly hygroscopic materials. Fig. 10 gives the sorption isotherms of the three studied hemp concretes. These curves are sigmoid and are classified as type II or III according to the IUPAC's classification [24]. This is consistent with the fact that these classes are given for macroscopic media. Moreover, these sorption curves show hysteresis which extends to the lowest pressures.

The sorption curves of sprayed and moulded hemp concretes are close to each other. Their water contents are similar for adsorption and for desorption branches, leading to similar hysteresis. For low and middle relative humidity, the gravimetric water content increases slightly versus relative humidity to reach about $3 \%$ at $58 \% \mathrm{RH}$ for the adsorption branch. For higher relative humidity, the water content strongly increases and reaches about $20 \%$ at $97 \% \mathrm{RH}$. The sorption curve of precast hemp concrete differs from these curves. For relative humidity lower than $81 \%$, the water content shows slightly lower values for precast hemp concrete than for sprayed and moulded hemp concretes. The slope of the sorption curve is also lower for PHC than for SHC and for MHC. For relative humidity higher than $81 \%$, the increase in water content is greater for precast hemp concrete leading to much higher water content: at $97 \% \mathrm{RH}$, the gravimetric water content is about $44 \%$

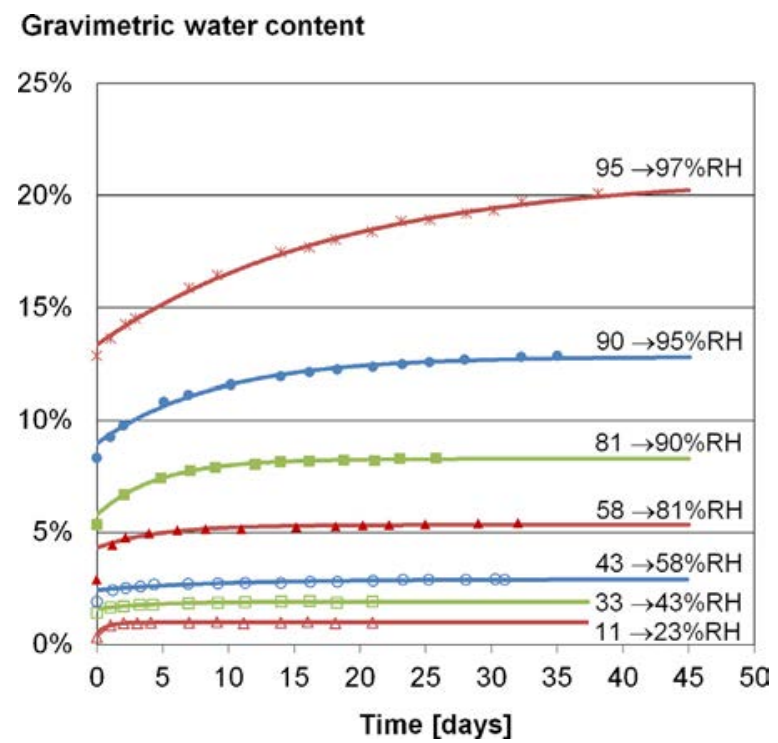

Fig. 9. Kinetics of adsorption of one specimen of sprayed hemp concrete (points: experimental data - lines: model of kinetic). for PHC. In this range of relative humidity, capillary condensation appears intense for PHC, while it starts gradually and occurs on a wide range of relative humidity for SHC and MHC. According to the $\mathrm{BJH}$ Method [27,17], in the range of relative humidity $81-97 \% \mathrm{RH}$, the capillary condensation occurs in pores of width from 0.005 to $0.040 \mu \mathrm{m}$. This size of pore is met in the skin of the cell wall of hemp shiv and in the inter-particle pores of the binder. Sprayed and moulded hemp concretes are made of the same binder and the same hemp/binder ratio so they logically show similar behaviour. Precast hemp concrete having a higher hemp/binder ratio leads to higher water content at high relative humidity. Table 3 gives the fitting parameters of the GAB model for the three hemp concretes. This fitting is held on experimental data up to $95 \% \mathrm{RH}$. The correlation coefficient between experimental data and fitting curves is higher than 0.998. Adding the 97\% RH experimental data with the same fitting curve, the correlation coefficient remains higher than 0.98. In line with the previous comments, the parameters are similar for SHC and MHC and slightly differ for PHC.

Adsorption and desorption branches are nearly parallel over a wide range of relative humidity for the three hemp concretes (Fig. 10). The hysteresis observed for precast hemp concrete is less important than the one observed with sprayed and moulded hemp concretes, as shown in Fig. 11. For the three materials, the highest hysteresis is observed around $80 \% \mathrm{RH}$. At middle relative humidity, the hysteresis is about $4 \%$ for the sprayed and the moulded hemp concretes and slightly lower than $3 \%$ for the precast hemp concrete. This hysteresis is commonly explained by the capillary condensation hysteresis, the contact angle hysteresis and the inkbottle effect [41]. After desorption, an outgas at higher temperature leads to lower residual moisture content values. So, the low pressure hysteresis can be attributed on the one hand to the presence of micropores and on the other hand to irreversible uptake of molecules in pores (or through pore entrances) of the same width as that of the adsorbate, or to irreversible chemical interaction of the adsorbate with the adsorbent [24]. Lastly, a part of the residual mass may also be due to the start of lime carbonation that probably occurred during the tests at high relative humidity.

Xie et al. [25] provide an example of adsorption-desorption curve of pure hemp shiv and Zaknoune [42] gives desorption curves of used hemp shiv. These curves are similar to each other. They are sigmoid and reach $25 \%$ of moisture content at highest relative

Table 3

Fitting parameters of the GAB model for the three hemp concretes.

\begin{tabular}{llll}
\hline Material & PHC & SHC & MHC \\
\hline$w_{m}$ & 0.0104 & 0.0130 & 0.0124 \\
$C_{G}$ & 0.8586 & 6.5615 & 2.1928 \\
$k$ & 1.0021 & 0.9463 & 0.9499 \\
\hline
\end{tabular}




\section{Gravimetric Water Content [\%]}
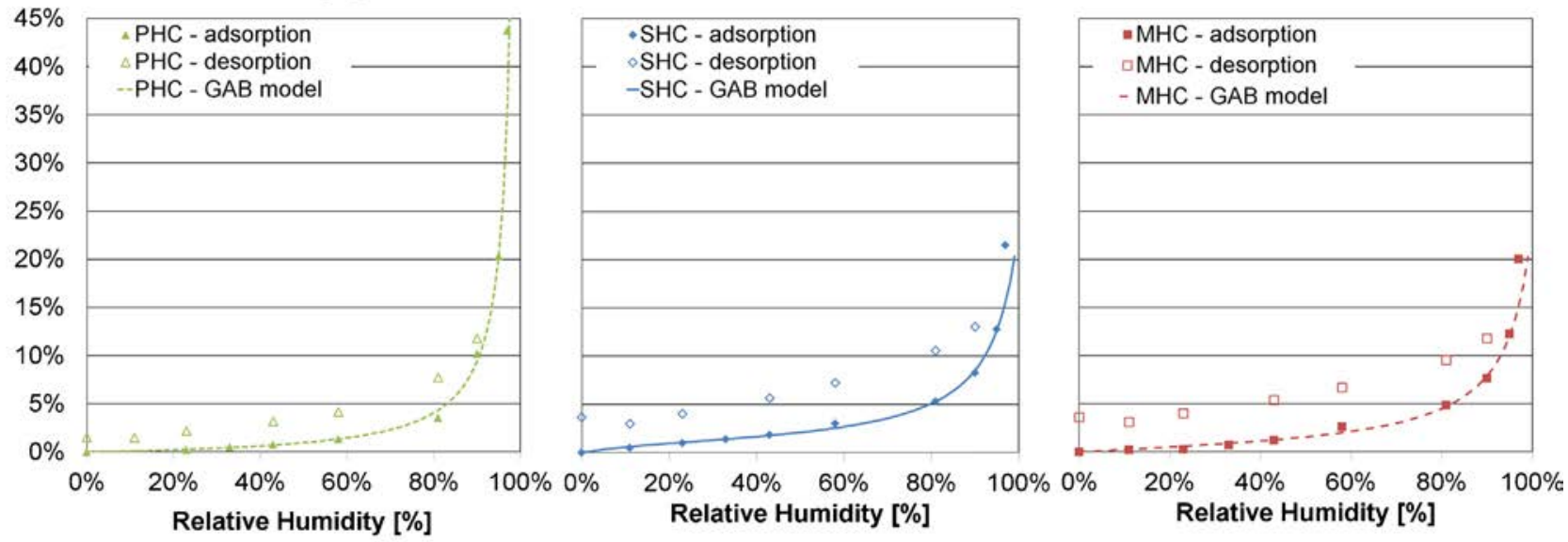

\section{Gravimetric Water Content [\%]}
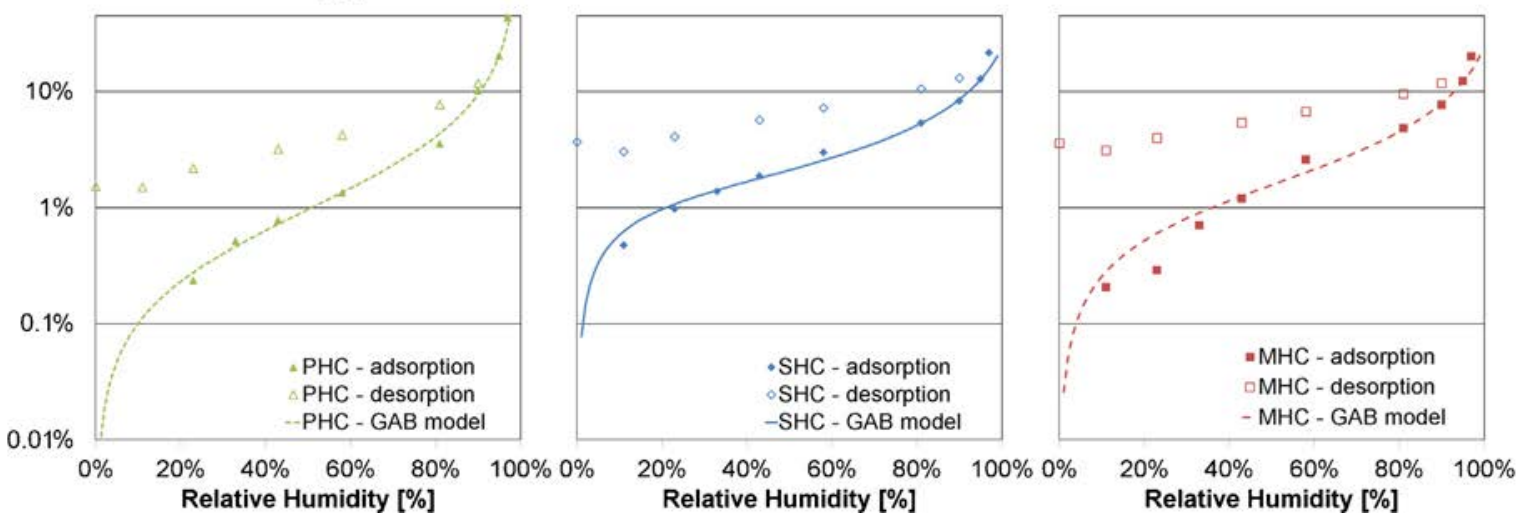

Fig. 10. Sorption isotherm of studied hemp concretes - top: linear plot; bottom: semilogarithmic plot.

humidity. At low and middle relative humidity, their water content ranges from about $3.5 \%$ at $20 \% \mathrm{RH}$ and $16 \%$ at $80 \% \mathrm{RH}$. Moreover, the hysteresis remains lower than $2 \%$ over the $\mathrm{RH}$ range. So, hemp concretes show lower sorption curves than hemp shiv but induce larger hysteresis. The porosity of the binder largely influences the hygroscopic behaviour of the mix.

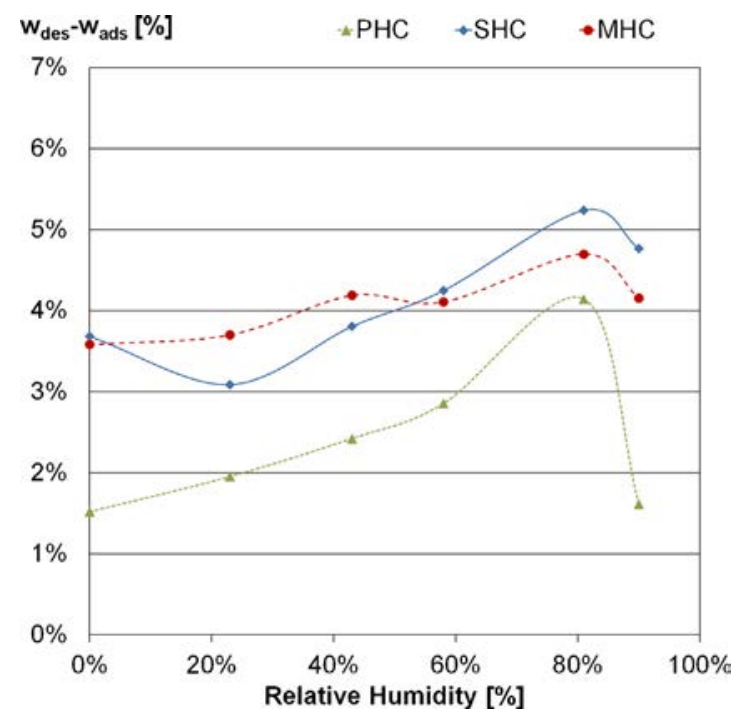

Fig. 11. Hysteresis loop between adsorption and desorption branches versus relative humidity.

\subsection{Water vapour permeability}

Fig. 12 gives an example of the kinetic of mass during a water vapour permeability test. For all the tests, the steady state is reached after ten to twenty days. The test goes on up to the saturation of silica gel or of saturated salt solutions. The water vapour permeability is then calculated from the slope of the kinetic of mass along 20-40 days during steady-state.

Fig. 13 gives the variation of moisture permeability versus ambient relative humidity for the three hemp concretes. Experimental data are fitted with a power law relationship (8). The fitting parameters are given in Table 4.

Moulded hemp concrete shows a slight increase of water vapour permeability from $1.7 \times 10^{-11}$ to $6.2 \times 10^{-11} \mathrm{~kg} \mathrm{~m}^{-1} \mathrm{~s}^{-1} \mathrm{~Pa}^{-1}$. Sprayed and precast hemp concretes show similar results with a nearly constant value of water vapour permeability for low and middle relative humidity (about $3.2 \times 10^{-11}$,

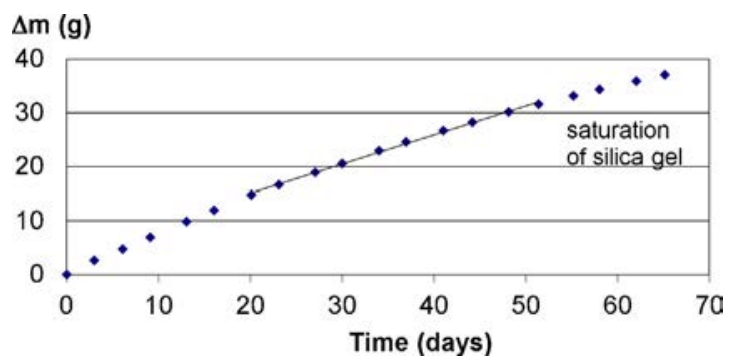

Fig. 12. Kinetic of mass of one specimen of precast hemp concrete during the cup test. 


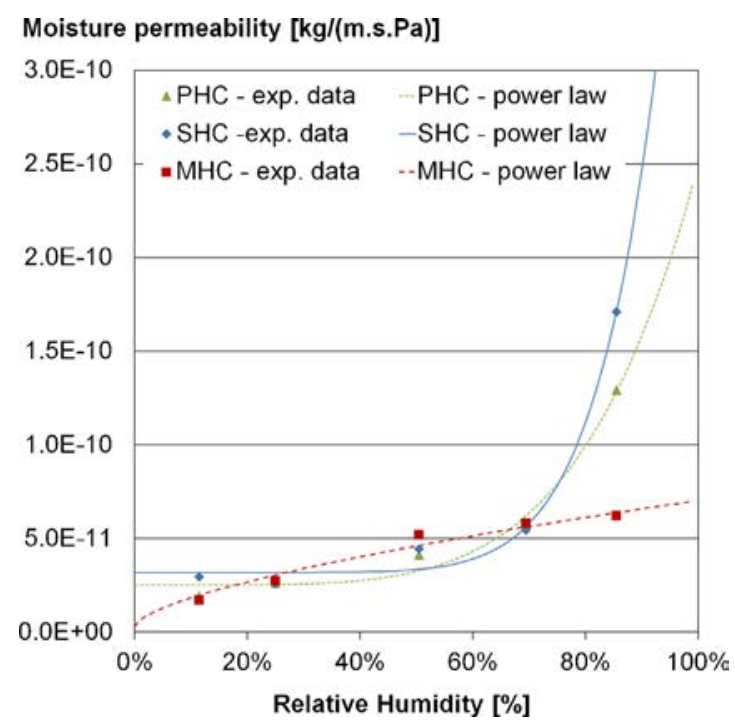

Fig. 13. Variation of moisture permeability versus ambient relative humidity.

Table 4

Variation of water vapour permeability versus relative humidity: fitting parameters of the power-law relationship.

\begin{tabular}{llll}
\hline Material & PHC & SHC & MHC \\
\hline A & $2.52 \mathrm{E}-11$ & $3.19 \mathrm{E}-11$ & $3.24 \mathrm{E}-12$ \\
B & $2.24 \mathrm{E}-10$ & $5.18 \mathrm{E}-10$ & $6.70 \mathrm{E}-11$ \\
C & 4.94 & 8.38 & 0.65 \\
\hline
\end{tabular}

resp. $\left.2.5 \times 10^{-11} \mathrm{~kg} \mathrm{~m}^{-1} \mathrm{~s}^{-1} \mathrm{~Pa}^{-1}\right)$. For high relative humidity, an abrupt increase appears: moisture permeability reaches $1.7 \times 10^{-10} \mathrm{~kg} \mathrm{~m}^{-1} \mathrm{~s}^{-1} \mathrm{~Pa}^{-1}$ (resp. $1.3 \times 10^{-10}$ ). The increase of the water vapour permeability with relative humidity is due to the enhancement of macroscopic moisture transport induced by microscopic liquid transfer in water filled pores (due to capillary condensation). For hysteretic materials, the water vapour permeability thus depends on the moisture content [43].

Fig. 14 shows the variation of moisture permeability versus water content considering the main adsorption curve for the determination of water content. For lowest values of water content (up to $4 \%$ ), the moisture permeability is similar for the three hemp concretes and follows a power law relationship. For highest

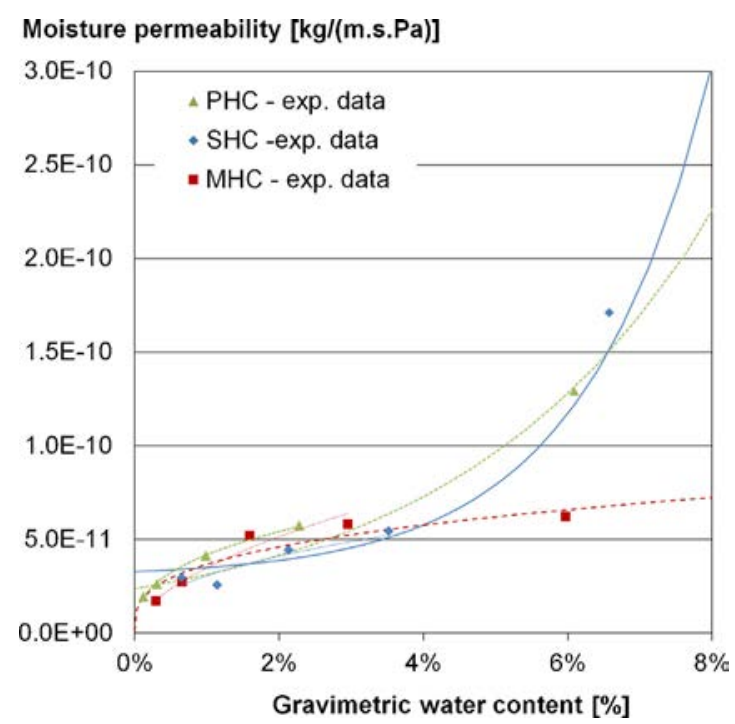

Fig. 14. Variation of moisture permeability versus gravimetric water content.

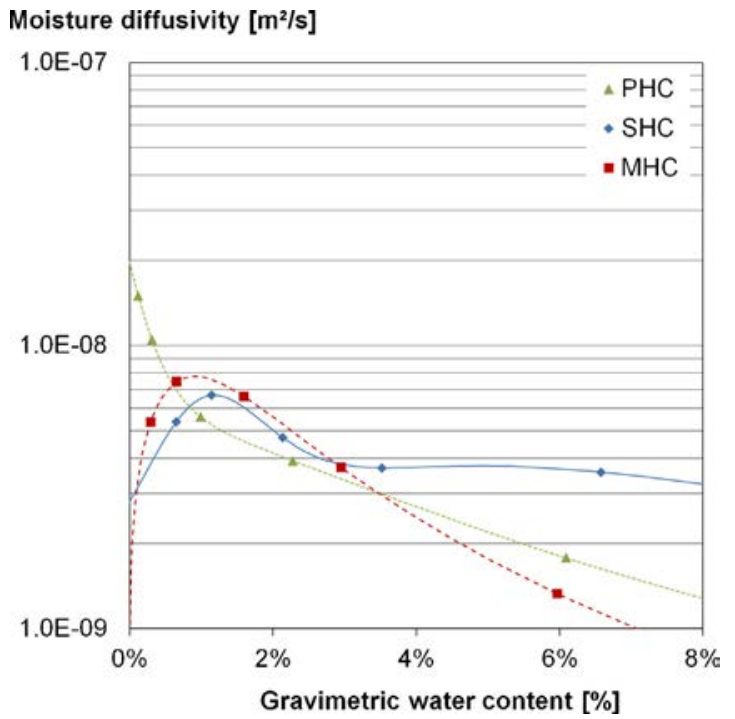

Fig. 15. Variation of moisture diffusivity versus gravimetric water content.

values of water content, the moisture permeability of moulded hemp concrete evolves following the same fitting curve while sprayed and precast hemp concrete show an exponential increase. This underlines the efficiency of microscopic liquid flow due to capillary condensation in open porosity.

\subsection{Moisture diffusivity}

Fig. 15 gives the variation of moisture diffusivity versus gravimetric water content. The hydric diffusivity is in the range $1.3 \times 10^{-9}$ to $1.5 \times 10^{-8} \mathrm{~m}^{2} / \mathrm{s}$. The shape of these curves is in agreement with De Vries theory: the first wave corresponding to hydric diffusivity under vapour transfer is observed. For precast hemp concrete, only the decrease of diffusivity is perceived. At lowest water content, the moisture diffusivity of precast hemp concrete is highest. It soon becomes the lowest: when water content reaches $0.8 \%$. Moulded and sprayed hemp concretes show similar variation of hydric diffusivity. In a first part, the moisture diffusivity increases up to $7.8 \times 10^{-9} \mathrm{~m}^{2} / \mathrm{s}$ (resp. $6.7 \times 10^{-9} \mathrm{~m}^{2} / \mathrm{s}$ ) for water content equal to $0.9 \%$ (resp. $1.1 \%$ ). Moisture transfer occurs through a "diffusion and effusion of vapour" phase. Then moisture diffusivity decreases in a similar way for the two materials. Due to capillary condensation, moisture transfer occurs by mechanisms of condensation and evaporation at vapour-liquid interfaces. When moisture content is equal to $3 \%$, the moisture diffusivity reaches down to $3.7 \times 10^{-9} \mathrm{~m}^{2} / \mathrm{s}$. Lastly, the moisture diffusivity of sprayed hemp concrete is nearly constant while it goes on decreasing for moulded hemp concrete. For sprayed and moulded hemp concrete, the sorption curves being very close to each other, the difference in moisture diffusivity is mainly due to the difference in moisture permeability for high water content (i.e. $\mathrm{RH}$ ).

\subsection{Moisture buffer value}

Fig. 16 gives an example of the kinetic of mass during the test. The kinetic is similar for all the specimens of the three hemp concretes. The steady state is reached from the fourth cycle: the change in mass $\Delta m$ and the moisture buffer value vary less than $5 \%$ within each cycle.

Table 5 gives the average value of the moisture buffer value calculated from cycles 4 to 7 in adsorption, desorption and the average for the three materials. The value is very slightly higher in desorption than in adsorption. 


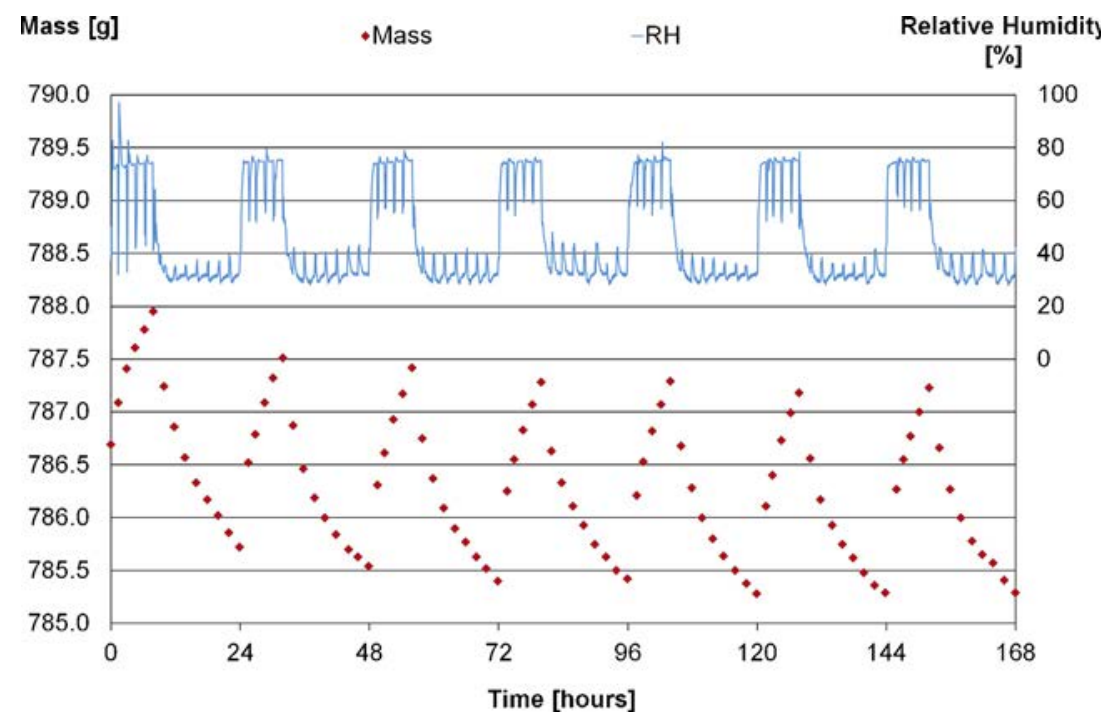

Fig. 16. Moisture uptake and release for the specimen SHC 4.5 and monitored relative humidity.

Table 5

Moisture buffer value in adsorption, desorption and average for the three kind of hemp concrete.

\begin{tabular}{llll}
\hline Material & PHC & SHC & MHC \\
\hline MBV - adsorption $\left[\mathrm{g} /\left(\mathrm{m}^{2} \% \mathrm{RH}\right)\right]$ & 1.91 & 2.14 & 2.12 \\
MBV - desorption $\left[\mathrm{g} /\left(\mathrm{m}^{2} \% \mathrm{RH}\right)\right]$ & 1.97 & 2.15 & 2.17 \\
MBV - average $\left[\mathrm{g} /\left(\mathrm{m}^{2} \% \mathrm{RH}\right)\right]$ & $\mathbf{1 . 9 4}$ & $\mathbf{2 . 1 5}$ & $\mathbf{2 . 1 4}$ \\
\hline
\end{tabular}

Sprayed and moulded hemp concretes show similar values of MBV (respectively 2.15 and $2.14 \mathrm{~g} /\left(\mathrm{m}^{2} \% \mathrm{RH}\right)$ in average) while precast hemp concrete shows a lower value $\left(1.94 \mathrm{~g} /\left(\mathrm{m}^{2} \% \mathrm{RH}\right)\right)$.

This is consistent with the results obtained previously. Actually, the moisture buffer value is proportional to the moisture effusivity of the material [36]. The moisture effusivity is linked to the moisture permeability and to the derivative of the sorption isotherm [6]. As the precast hemp concrete shows a lower derivative of sorption curve and a smaller hysteresis than sprayed and moulded hemp concrete, it has a lower moisture buffering capacity. Thus, its moisture buffer value is logically lower than the one for SHC and MHC.

Lastly, according to the classification of the NORDTEST Project, these materials appear as excellent (MBV $>2 \mathrm{~g} /\left(\mathrm{m}^{2} \% \mathrm{RH}\right)$ ) or nearly excellent (good: $1<\mathrm{MBV}<2 \mathrm{~g} /\left(\mathrm{m}^{2} \% \mathrm{RH}\right)$ ) hygric regulators.

\section{Conclusions}

The three studied materials are highly porous, with open and interconnected porosity. The results underline their high moisture transfer and storage capacities; they are classified as excellent (or nearly excellent) hygric regulators.

The results obtained for sorption curves are very close for two of the three hemp concretes (SHC and MHC): these materials are made of the same binder and the same hemp shiv/binder ratio. The sorption curve of the third hemp concrete (PHC) leads to lower moisture content for low and middle relative humidity. For high relative humidity, the moisture variation is more abrupt, in connection with capillary condensation phenomena in open porosity (cell wall of hemp shiv and inter-particles porosity of binder). The three hemp concretes show a high hysteresis loop between adsorption and desorption curves. The hysteresis is slightly lower for the precast hemp concrete. The water vapour permeability of the three hemp concretes is high $\left(1.7 \times 10^{-11}\right.$ to $\left.1.7 \times 10^{-10} \mathrm{~kg} \mathrm{~m}^{-1} \mathrm{~s}^{-1} \mathrm{~Pa}^{-1}\right)$. For two of the three materials
(PHC and SHC), it increases widely at high relative humidity, in connection with microscopic liquid flow in open porosity. The moisture diffusivity ranges between $1.3 \times 10^{-9}$ and $1.5 \times 10^{-8} \mathrm{~m}^{2} / \mathrm{s}$ and is essentially linked to vapour transfer, while liquid transfer appears negligible for relative humidity lower than $80 \%$. Lastly, in the same way as for sorption curves, the moisture buffer values of two materials ( $\mathrm{SHC}$ and MHC) are close while it is slightly lower for the third one (PHC). For the three hemp concretes, the moisture buffer values are excellent, showing the ability of the material to regulate ambient relative humidity. Finally, it seems that the composition and the manufacturing method have a low, but non negligible, impact on hygric properties of hemp concretes.

All these data appear necessary to simulate the hygrothermal behaviour of the building envelope. The use of sorption curve and water vapour permeability alone cannot lead to a good prediction of hysteretic behaviour. Actually, it was shown that uncertainty on this kind of data hampers reliable simulation of hygroscopic buffering [5]. Moreover, measurement of the sorption curve and water vapour permeability is long and tedious. So, dynamic testing of the moisture buffer value is a good additional dynamic test to evaluate the moisture buffer capacity of materials. Additionally, the data from this test can be used for benchmarking buffering models but does not lead directly to sorption and permeability values. A reverse method should be built to identify characteristic parameters from an MBV test.

Lastly, it should be emphasised that the moisture buffering capacity of these materials would allow energy savings while maintaining adequate air quality and hygrothermal comfort [22,23]. However, in most cases, hemp concrete is plastered. The slight difference between the three hemp concretes would thus probably be reduced once they have been plastered, while the moisture buffering capacity of the wall would be lower.

\section{Acknowledgments}

This article presents results following the French national project ANR-06-MAPR-0002 "Béton de chanvre" - Programme MAPR 2006 and the Breton regional project "PRIR Ecomatx". These projects were conducted with the financial support of the French National Research Agency (ANR) and the Brittany Regional Council.

The authors thank the SMEs Easy Chanvre and SI2C for their contribution to the manufacturing of hemp concrete. 


\section{References}

[1] S. Cerolini, M. D’Orazio, C. Di Perna, A. Stazi, Moisture buffering capacity of highly absorbing materials, Energy and Buildings 41 (2009) 164-168.

[2] C.J. Simonson, M. Salonvaara, T. Ojanen, Heat and mass transfer between indoor air and a permeable and hygroscopic building envelope: part 1 - field measurements, Journal of Thermal Envelope and Building Science 28 (1) (2004) 63-101.

[3] C.J. Simonson, M. Salonvaara, T. Ojanen, Heat and mass transfer between indoor air and a permeable and hygroscopic building envelope: part 2 - verification and numerical studies, Journal of Thermal Envelope and Building Science 28 (2) (2004) 161-185.

[4] O.F. Osanyintola, C.J. Simonson, Moisture buffering capacity of hygroscopic building materials: experimental facilities and energy impact, Energy and Buildings 38 (2006) 1270-1282.

[5] S. Roels, P. Talukdar, C. James, C.J. Simonson, Reliability of material data measurements for hygroscopic buffering, International Journal of Heat and Mass Transfer 53 (2010) 5355-5363.

[6] C. Rode, R. Peuhkuri, K.K. Hansen, B. Time, K. Svennberg, J. Arfvidsson, T. Ojanen, Moisture buffer value of materials in buildings, Journal of ASTM international 4 (May (5)) (2007).

[7] Japanese Industrial Standard A 1470-1, Determination of water vapour adsorption/desorption properties for building materials: part 1 - response to humidity variation, 2008

[8] ISO/DIS 24353, Hygrothermal performance of building materials and products - determination of moisture adsorption/desorption properties in response to humidity variation, 2006

[9] O.F. Osanyintola, P. Talukdar, C.J. Simonson, Effect of initial conditions, boundary conditions and thickness on the moisture buffering capacity of spruce plywood, Energy and Buildings 38 (2006) 1283-1292.

[10] M.-P. Boutin, C. Flamin, S. Quinton, G. Gosse, Etude des caractéristiques environnementales du chanvre par l'analyse de son cycle de vie, INRA Lille, France, 2005 (in French).

[11] C. Garnier, S. Prétot, F. Collet, Life assessment of hemp concrete wall manufactured by spraying, in: 2nd International conference on building energy and environment, Boulder, Colorado, 2012.

[12] S. Elfordy, F. Lucas, F. Tancret, Y. Sculler, L. Goudet, Mechanical and thermal properties of lime and hemp concrete ("hempcrete") manufactured by projection process, Construction and Building Materials 22 (10) (2008) 2116-2123.

[13] L. Arnaud, E. Gourlay, Experimental study of parameters influencing mechanical properties, Construction and Building Materials 28 (2012) 50-56.

[14] P.B. de Bruijn, K.H. Jeppson, K. Sandin, C. Nilsson, Mechanical properties of lime-hemp concrete containing shives and fibres, Biosystems Engineering 103 (4) (2009) 474-479.

[15] L. Arnaud, Mechanical and thermal properties of hemp mortars and wools: experimental and theoretical approaches, in: 3 Symp Int of bioresource hemp, 2000.

[16] S. Pretot, F. Collet, P. Glouannec, V. Lang, Variation des propriétés thermiques de bétons de chanvre en fonction de la formulation, in: Congrès français de thermique-Efficacité énergétique, Vannes, Tome 2, Editions Société Française de Thermique, 2009, pp. 865-870, ISBN 2-905267-67-2 (in French).

[17] F. Collet, M. Bart, L. Serres, J. Miriel, Porous structure and water vapour sorption of hemp-based materials, Construction and Building Material 22 (2008) $1271-1280$

[18] A. Evrard, A. De Herde, Hygrothermal performance of lime-hemp wall assemblies, Journal of Building Physics 34 (2010) 15-25.

[19] F. Collet, S. Pretot, Experimental investigation of moisture buffering capacity of sprayed hemp concrete, Construction and Building Materials 36 (2012) 58-65.

[20] S. Pretot, F. Collet, Experimental Study of Hygrothermal Behavior of a Hemp Concrete Wall (Without and With Coating), in: 2nd International Conference on Building Energy and Environment, Boulder, Colorado, August 1-4, 2012.
[21] A. Shea, M. Lawrence, P. Walker, Hygrothermal performance of an experimental hemp-lime building, Construction and Building Materials 36 (2012) 270-275.

[22] A. Evrard, A. De Herde, Hygrothermal performance of lime-hemp wall assemblies, Journal of Building Physics 34 (2010) 15-25.

[23] A.D. Tran Le, C. Maalouf, T.H. Mai, E. Wurtz, F. Collet, Transient hygrothermal behavior of a hemp concrete building envelope, Energy and Buildings 42 (2010) 1797-1806.

[24] International Union of Pure and Applied Chemistry, Reporting physisorption data for gas/solid systems with special reference to the determination of surface area and porosity, Pure and Applied Chemistry 57 (4) (1986) 603-619.

[25] Y. Xie, C.A.S. Hill, Z. Jalaludin, S.F. Curling, R.D. Anandjiwala, A.J. Norton, G. Newman, The dynamic water sorption behaviour of natural fibres and kinetic analysis using the parallel exponential kinetics model, Journal of Materials Science 46 (2011) 479-489.

[26] S. Brunauer, P.H. Emmet, E. Teller, Adsorption of gases in multimolecular layers, Journal of the American Chemical Society 60 (1938) 309-319.

[27] E.P. Barett, L.G. Joyner, P.P. Halenda, The determination of pore volume and area distributions in porous substances - I. Computations from nitrogen isotherms, Journal of American Chemical Society 73 (1951) 373-380.

[28] E.A. Guggenheim, Application of Statistical Mechanics, Clarendon Press, Oxford, 1966 (Chapter 11).

[29] R.B. Anderson, Modifications of the Brunauer, Emmett and Teller, Journal of the American Chemical Society 68 (4) (1946) 686-691.

[30] R.B. Anderson, W.K. Hall, Modifications of the Brunauer, Emmett and Teller, equation II, Journal of the American Chemical Society 70 (5) (1948) 1727-1734.

[31] J.H. De Boer, The Dynamical Character of Adsorption, Clarendon Press, Oxford, 1953.

[32] G.H. Galbraith, R.C. McLean, J. Guo, Moisture permeability data presented as a mathematical function applicable to heat and moisture transport models, in: Building Simulation 1997, Prague, Czech Republic, P200, September 8-10, 1997.

[33] R. McLean, G. Galbraith, C. Sanders, Moisture transmission testing of building materials and the presentation of vapor permeability values, Building Research and Practice 2 (1990) 82-91.

[34] A. Tveit, Measurements of moisture sorption and moisture permeability of porous materials, report 45, Norwegian Building Research Institute, Oslo, 1966.

[35] D.A. De Vries, Simultaneous transfer of heat and moisture in porous media, Eos Transactions, American Geophysical Union 39 (1958) 909-916.

[36] C. Rode, Moisture Buffering of Building Materials, Report BYG.DTU R-126, 2005, ISSN 1601-2917, ISBN 87-7877-195.

[37] R. Peuhkuri, C. Rode, Using dynamic moisture loading tests for the determination of moisture buffer value, in: Annex 41 Meeting, Montreal, 16-18 May, 2005.

[38] S. Amziane, L. Arnaud (Eds.), Bio-aggregate-based Building Materials: Applications to Hemp Concretes, ISTE Ltd. and John Wiley \& Sons Inc., 2013, ISBN 9781848214040

[39] Règles Professionnelles d'Exécution d'Ouvrage en Bétons de Chanvre, Association Construire en chanvre, 2007 (in French).

[40] A. Evrard, Transient hygrothermal behavior of Lime-Hemp materials, Ph.D. Thesis, Université catholique de Louvain, 2008.

[41] H. Derluyn, D. Derome, J. Carmeliet, E. Stora, R. Barbarulo, Hysteretic moisture behavior of concrete: modelling and analysis, Cement and Concrete Research 42 (2012) 1379-1388.

[42] A. Zaknoune, Etude du comportement thermohydrique de matériaux " chanvre-chaux " lors de la phase de séchage - estimation par technique inverse des propriétés hydriques, Ph.D. Thesis, Université de Bretagne Sud, December 2011 (in French)

[43] D. Derome, H. Derlyun, W. Zillig, J. Carmeliet, Model for hysteretic moisture behavior of wood, Proceedings of the Nordic Symposium on Building Physics 2 (2008) 959-966. 